\title{
A PROMISING DNA GROOVE BINDER AND PHOTOCLEAVER BASED ON A DINUCLEAR RUTHENIUM(II) COMPLEX
}

\author{
YA-XUAN MI ${ }^{a}$, SHUANG WANG ${ }^{a}, X U E-X U E X U^{a}, H U A-Q I A N Z H A O^{a}, Z E-B A O Z H E N G^{* b}$, \\ $X I A O-L O N G$ ZHAO*a
}

${ }^{a}$ College of Chemistry \& Environmental Science, Hebei University, Baoding 071002, P.R. China

${ }^{b}$ College of Chemistry and Chemical Engineering, Taishan University, Taian 271021, P.R. China

\section{ABSTRACT}

A dinuclear ruthenium complex $\left[\mathrm{Ru}_{2}(\text { bpy })_{4}\right.$ (bip-phenol) $]\left(\mathrm{ClO}_{4}\right)_{4}\left\{\right.$ bpy $=2,2^{\prime}$-bipyridine, bip-phenol $=2,4$-bis $(1 H$-imidazo[4,5- $f[1,10]$ phenanthrolin-2-yl $)$ phenol $\}$ has been synthesized and characterized. The calf thymus (ct) DNA binding properties of the complex are investigated by means of DNA viscosity and optical spectroscopic techniques of UV-visible absorption and emission spectral titrations, steady-state emission quenching with ferrocyanide, ethidium bromide competitive binding, DNA thermal denaturation and reverse salt effect, together with molecular simulation technology. The results suggest that the complex is a promising DNA groove binder with a large DNA binding constant on $10^{6} \mathrm{M}^{-1}$ order of magnitude. The fluorescence of the complex manifests by 6.3 -fold upon binding saturately to DNA. The complex is also demonstrated to be an efficient photocleaver of pBR 322 DNA.

Keywords Ruthenium(II) complex; Calf thymus DNA; Groove mode.

\section{INTRODUCTION}

The interaction of metal complexes with nucleic acids is a major area of interdisciplinary research activity which is stimulated by an interest in topics such as the exploring DNA probes and the design of photoreagents and chemotherapeutic agents. ${ }^{[1-7]}$ Since the pioneering report of DNA binding properties of $\Delta$ - and $\Lambda$ - $\left[\mathrm{Ru}(\mathrm{phen})_{3}\right]^{2+}$ (phen $=1,10$-phenanthroline) and DNA molecular light switch behaviors of $\mathrm{Ru}(\mathrm{phen})_{2}(\mathrm{dppz})^{2+}$ and $\mathrm{Ru}(\mathrm{bpy})_{2}(\mathrm{dppz})^{2+}$ $\left(\mathrm{dppz}=\right.$ dipyrido $\left[3,2-a: 2^{\prime}, 3^{\prime}-c\right]$ phenazine $)$ by Barton et al., the last few decades have seen an increased interest in ruthenium(II) polypyridyl complexes as promising DNA structural probes, DNA footprinting, sequence specific cleaving and antitumor agents due to their excellent chemical stability, facile electron transfer, strong luminescent emission, and relatively long-lived excited states. ${ }^{[1-6,8]}$ However, most of these Ru(II) complexes are mononuclear, which unfortunately exhibit some significant drawbacks as DNA binders and structural probes. For example, the mononuclear Ru(II) complexes are relatively small and span only $1-2$ DNA base pairs; these mononuclear complexes have weak DNA binding affinity $\left(K_{\mathrm{b}} \approx 10^{4}-10^{6} \mathrm{M}^{-1}\right.$, depending on the intercalators) and are easily displaced from DNA at high ionic strength. ${ }^{[9,10]}$ Compared to analogous mononuclear complexes, the dinuclear Ru(II) complexes that in general have increased size and charge, varied molecular shapes, DNA structural selectivity and great DNA binding affinity could overcome above mentioned drawbacks. While only a limited attention has been focused on the DNA binding studies of dinuclear Ru(II) complexes. ${ }^{6,10,11-22}$ A dinuclear $\mathrm{Ru}(\mathrm{II})$ complex $\left[\left\{(\mathrm{bpy})_{2} \mathrm{Ru}\right\}_{2}(4 \text {-azo })\right]^{4+}\left\{\right.$ bpy $=2,2^{\prime}$-bypyridine), 4 -azo $=4,4^{\prime \prime}$-azobis $\left(2,2^{\prime}\right.$-bipyridine $\left.)\right\}$ was found to groove binds to DNA and functions as a colorimetric sensor for different sequence and structure of DNA. [21] Complexes of $\left[\mu \text {-bidppz(phen) } \mathrm{Ru}_{2}\right]^{4+}\left\{\right.$ bidppz $=11,11^{\prime}$-bi(dipyrido[3,2$\left.a: 2^{\prime}, 3^{\prime}-c\right]$ phenazinyl $\left.)\right\}$ and $\left[\mu \text {-dppzip(phen) }{ }_{4} \mathrm{Ru}_{2}\right]^{4+}\{$ dppzip $=2-(\operatorname{dipyrido}[3,2-$ $\left.a: 2^{\prime}, 3^{\prime}-c\right]$ phenazin-11-yl)imidazo $[4,5-f][1,10]$ phenanthroline) $\}$ display unusual threading intercalation interaction with DNA. ${ }^{[16]}$ Dinuclear monointercalating

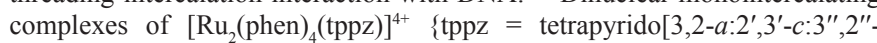
$\left.h: 2^{\prime \prime}, 3^{\prime \prime}-j\right]$ phenazine $\}$ and $\left[\mathrm{Ru}_{2}(\mathrm{bpy})(\mathrm{tppz})\right]^{4+}$ exhibit high affinity binding to DNA even at $200 \mathrm{mM} \mathrm{KCl}$ aqueous buffer $\left(K_{\mathrm{b}} \approx 10^{6} \mathrm{M}^{-1}\right)$ and the DNA binding was accompanied by a distinctive light switch with large steady-state luminescent enhancements of $>60$ times ${ }^{[12]}$ A dinuclear complex reported by our group of $\left[\mathrm{Ru}_{2}(\text { bpy })_{4}\left(\mathrm{H}_{2} \text { bipt }\right)\right]^{4+}\left\{\mathrm{H}_{2}\right.$ bipt $=2,5$-bis $[1,10]$ phenanthrolin $[4,5-$ $f$-imidazol-2-yl)thiophene $\}$ was shown to bind to DNA probably through mixed binding modes of classic intercalation and partial intercalation, and exert efficient photocleavage ability and antitumor activity selectively against MCF-7 cell line. ${ }^{[22]}$

It is noteworthy that of the dinuclear Ru(II) complexes reported, many of them have been shown to bind to DNA through threading monointercalation, or threading bis-intercalation..$^{9,11-20]}$ We have put much attention on DNA intercalation for dinuclear $\mathrm{Ru}(\mathrm{II})$ complexes, while only a few dinuclear $\mathrm{Ru}(\mathrm{II})$ complexes have been reported to groove bind to DNA or partial intercalate to DNA, to the best of our knowledge. ${ }^{[21,22]}$ As with intercalators, groove binders can also be used as chemotherapeutic agents, such as clinical treatment of cancer and bacterial infections, so the groove binding need more exploration for structure-function relationship. ${ }^{[23-27]}$ On the other hand, the dinuclear $\mathrm{Ru}(\mathrm{II})$ complexes that possess DNA cleavage activity are not common either. ${ }^{[12,22]}$ The DNA cleavage of Ru(II) complexes is related to their utility in design and development of synthetic restriction enzymes, DNA footprinting agents and so on. Therefore, the Ru(II) complexes induced DNA cleavage behaviors need further investigated. As part of our ongoing studies aimed at DNA binding, DNA photocleavage and luminescence DNA sensing based on dinuclear $\mathrm{Ru}$ (II) complexes, we present here our interesting findings on a complex $\left[\mathrm{Ru}_{2}(\text { bpy })_{4}(\right.$ bip-phenol $\left.)\right]\left(\mathrm{ClO}_{4}\right)_{4} \quad$ bip-phenol $=2,4$-bis $(1 H$-imidazo $[4,5-f$ $[1,10]$ phenanthrolin-2-yl)phenol $\}$ : avid binding to DNA through groove mode with binding constant of $(2.50 \pm 0.05) \times 10^{6} \mathrm{M}^{-1}$, significant manifestation of luminescence intensity (6.3) by interacting with DNA, and photocleavage of pBR 322 DNA effectively.

\section{EXPERIMENTAL SECTION}

\subsection{Reagents and materials}

The compound $\left[\mathrm{Ru}_{2}\right.$ (bpy) (bip-phenol) $]\left(\mathrm{ClO}_{4}\right.$ ) was prepared according to the methods described in the literature, ${ }^{[28]}$ and the synthetic route and synthetic details are given in the supporting information. The molecular structure of the complex is shown in Scheme 1. All solutions involving DNA experiments were prepared by thrice distilled water. Buffer A $(5 \mathrm{mM}$ Tris- $\mathrm{HCl}, 50 \mathrm{mM}$ $\mathrm{NaCl}, \mathrm{pH}=7.10 \pm 0.02$ ) was used for absorption titration, luminescence titration, steady-state emission quenching, ethidium bromide (EB) competition and viscosity measurements. Buffer $\mathrm{B}\left(1.5 \mathrm{mM} \mathrm{Na}_{2} \mathrm{HPO}_{4}, 0.5 \mathrm{mM} \mathrm{NaH} \mathrm{PO}_{4}\right.$, $0.25 \mathrm{mM} \mathrm{Na}{ }_{2}$ EDTA, $\mathrm{pH}=6.28 \pm 0.02$ ) was used for thermal denaturation experiments. Buffer $\mathrm{C}(50 \mathrm{mM}$ Tris- $\mathrm{HCl}, 18 \mathrm{mM} \mathrm{NaCl}, \mathrm{pH}=7.2)$ and $\mathrm{D}$ (TAE, $40 \mathrm{mM}$ Tris-CH3COOH, $1 \mathrm{mM}$ EDTA, $\mathrm{pH}=8.0$ ) were used for DNA photocleavage experiments. The calf thymus DNA (ct-DNA) was obtained from Shanghai Sangon Biological Engineering Technology \& Services (Shanghai, China) and used without further purification (long-term storage at $-20{ }^{\circ} \mathrm{C}$ ). A solution of ct-DNA in the buffer A (centrifuged for 20 minutes and incubated at $4{ }^{\circ} \mathrm{C}$ overnight) gave a ratio of UV absorbance at 260 and 280 $\mathrm{nm}$ of $1.8-1.9: 1$, indicating that the DNA was sufficiently free of protein. The DNA concentration per nucleotide was determined by absorption spectroscopy using the molar absorption coefficient $\left(6600 \mathrm{M}^{-1} \mathrm{~cm}^{-1}\right)$ at $260 \mathrm{~nm} \cdot{ }^{[29]}$

\subsection{DNA binding experiments}

The absorption spectra were recorded with a Shimadzu UV-3600 spectrophotometer. The emission spectra were obtained on a Shimadzu RF5301PC spectrofluorophotometer. The absorption and luminescence titrations of the complex with DNA were performed using a fixed concentration for complex to which increments of the DNA stock solution were added. The RuDNA solutions were allowed to incubate for $10 \mathrm{~min}$ before the absorption and luminescence spectra were recorded. The reverse salt titrations were carried out as absorption titrations but with varied concentrations of salts. All of the titration experiments were performed by using 1-cm-path quartz cuvettes at 
room temperature of $20^{\circ} \mathrm{C}$.

The steady-state quenching experiments were carried out by adding aliquots of ferrocyanide stock solution to the sample solutions containing DNA and ruthenium complex in buffer. The experiments of DNA competitive binding with $\mathrm{EB}$ were conducted in buffer by keeping $[\mathrm{DNA}] /[\mathrm{EB}]=5$ and varying the concentrations of ruthenium complex. The fluorescence spectra of EB were measured using excitation wavelength at $537 \mathrm{~nm}$. All solutions were allowed to equilibrate thermally for $10 \mathrm{~min}$ before measurements were made.

The thermal denaturation studies were performed on Shimadzu UV-3600 spectrophotometer equipped with a temperature-controlling programmer $\left( \pm 0.1^{\circ} \mathrm{C}\right)$. Solutions of DNA molecule both in the absence and presence of the ruthenium complex were prepared in buffer. All solutions were needed to incubate for an hour before being measured. The temperature of the solution was increased from 50 to $85^{\circ} \mathrm{C}$ at an increasing rate of $1{ }^{\circ} \mathrm{C} \cdot \mathrm{min}^{-1}$, and the absorbance at $260 \mathrm{~nm}$ was monitored every $1{ }^{\circ} \mathrm{C}$. The $T$ values were determined from plots of $\left(A-A_{0}\right) /\left(A_{\mathrm{f}}-A_{0}\right)$ versus temperature, where $A_{\mathrm{f},} A_{0}, A$ are the final, initial and observed absorbance at $260 \mathrm{~nm}$, respectively.

The viscosity measurements were carried out using an Ubbelodhe viscometer maintained at a constant temperature of $32.0 \pm 0.1{ }^{\circ} \mathrm{C}$ in a thermostatic bath. DNA samples approximately 200 base pairs in average length were prepared by sonication in order to minimize complexities arising from DNA flexibility. A digital stopwatch was used to measure the flow time, and each sample was measured three times and an average flow time was calculated. The viscosity values were calculated from the observed flow time of DNA-containing solutions $(\mathrm{t})$ corrected for that buffer alone $\left(t_{0}\right): \eta=\left(t-t_{0}\right)$. Data were presented as $\left(\eta / \eta_{0}\right)^{1 / 3}$ versus the $[\mathrm{Ru}] /[\mathrm{DNA}]$, where $\eta$ is the viscosity of DNA in the presence of the complex, and $\eta_{0}$ is the viscosity of DNA alone.

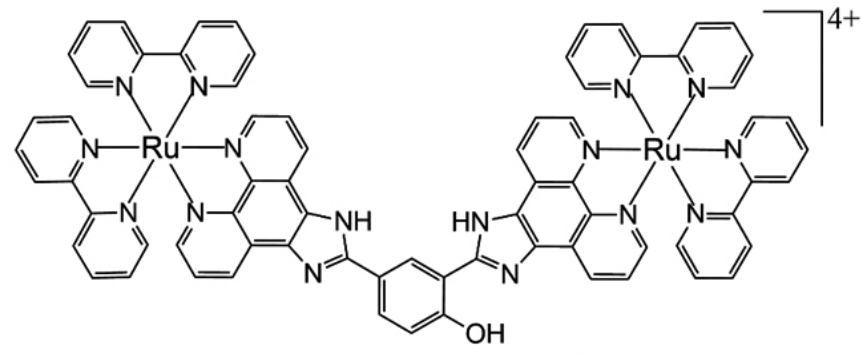

$\left[\mathrm{Ru}_{2}(\mathrm{bpy})_{4}(\text { bip-phenol) }]^{4+}\right.$

\subsection{Molecular docking}

Complex $\left[\mathrm{Ru}_{2} \text { (bpy) (bip-phenol) }\right]^{4+}$ consists of one $\mathrm{Ru}^{\mathrm{II}}$ ion, four ancillary ligands (bpy), and one main ligand (bip-phenol). Geometry optimizations of the complex with the help of Gaussian03 program were performed by the density functional B3LYP method with a mixed basis set, in which LANL2DZ was used for Ru and 6-31G* was applied for the other atoms. MGL tools 1.5.4 with AutoGrid4.2 and Autodock4.2 were used to perform the docking operation between the complex and duplex DNA of sequence d(CGCGAATTCGCG)2 (PDB 1D:1BNA) which was downloaded from Protein Data Bank. Before docking the water moleculars were removed from the receptor DNA and Gasteiger charges as well as hydrogens were added to it through Autodock4.2 Tools. As standard parameters for Ru(II) cannot be recognized in Autodock4.2 and zinc possess the same valence (II) and similar atomic radius with ruthenium, Zn (II) parameters were used intead. ${ }^{[30]}$

\subsection{DNA photocleavage experiments}

The photoinduced DNA cleavage by ruthenium complex was examined by gel electrophoresis. Supercoiled pBR 322 DNA $(0.2 \mu \mathrm{g})$ was treated with the ruthenium complex in buffer $\mathrm{C}$, and the solution was then irradiated at room temperature with UV light $(360 \mathrm{~nm})$ after incubation in the dark for $1 \mathrm{~h}$. The samples were analyzed by electrophoresis for $1 \mathrm{~h}$ at $80 \mathrm{~V}$ on a $0.8 \%$ agarose gel in buffer D. The gel was stained with $1 \mu \mathrm{g} \cdot \mathrm{mL}^{-1} \mathrm{~EB}$ and photographed under UV light.

\section{RESULTS AND DISCUSSION}

\subsection{UV-Vis absorption spectra}

The changes observed in the absorption spectra of small compounds in the presence of increasing amounts of DNA are widely used to determine the extent of their interaction with DNA. The absorption spectra of complex $\left[\mathrm{Ru} \mathrm{u}_{2} \text { (bpy) }{ }_{4} \text { (bip-phenol) }\right]^{4+}$ in the absence and the presence of the DNA are shown in Fig. 1. It can be seen that the electronic absorption spectra of the complex in aqueous solution showed three well-resolved bands centered at 285, 355 and $465 \mathrm{~nm}$ which are assigned to the intraligand $\pi-\pi^{*}$ (bpy) and $\pi-\pi^{*}$ (bip-phenol) transitions, and the superposition of $\mathrm{Ru}(\mathrm{d} \pi) \rightarrow \operatorname{bpy}\left(\pi^{*}\right)$ and $\mathrm{Ru}(\mathrm{d} \pi) \rightarrow$ bip-phenol $\left(\pi^{*}\right)$ metal-to-ligand charge transfer (MLCT) transitions, respectively, based on the comparisons with the absorption bands of $\left[\mathrm{Ru}(\mathrm{bpy})_{3}\right]^{2+}$. Upon titration with DNA, the complex exhibited obvious hypochromisms with hypochromicity $H$ values $\{H \%=100(A-A) /$,$A of 25,22$, and $11 \%$ for all the three bands at 285,355 and $465 \mathrm{~nm}$ with unapparent red shifts, because of the strong stacking interaction between the aromatic chromophore of the complex and DNA base pairs. ${ }^{[31]}$ It should be pointed out that not only intercalators but also groove binders have been reported to show considerable hypochromicities of the absorption bands upon binding to DNA, such as DNA groove binder of $\Delta \Delta$-[Ru, $\left.(\mathrm{bpy})_{4}(\mathrm{bdptb})\right]^{4+}\{\mathrm{bdptb}=$ (2,2'-bis(5,6-diphenyl-1,2,4-triazin-3yl)-4,4'-bipyridine $)\},{ }^{[32 !}$ intercalators of $\left[\mathrm{Ru}_{2}(\text { phen })_{4}\left(\mathrm{mbpibH}_{2}\right)\right]^{4+}\left\{\mathrm{mbpibH}_{2}\right.$ 1,3-bis(1,10-phenanthroline[5,6- $d$ ] imidazol-2-yl)-benzene $]\}^{[13]}$ and $\left[\mathrm{Ru}_{2}(\text { bpy })_{4}\left(\mathrm{ebipcH}_{2}\right)\right]^{4+}\left\{\right.$ ebipcH $_{2}=N$-ethyl-4,7-bis([1,10]-phenanthroline[5,6- $\left.f\right]$ imidazol-2-yl)carbazole $\},{ }^{[15]}$ and threading intercalators of $\left[\mathrm{Ru}_{2}(\mathrm{bpy})_{4}(\mathrm{~L})\right]^{4+}\{\mathrm{L}$ $=\mathrm{L}_{1}, \mathrm{~L}_{2}$ or $\mathrm{L}_{3}, \mathrm{~L}_{1}=1,2$-bis(4-(1H-imidazo[4,5-f][1,10]phenanthrolin-2-yl) phenoxy)ethane, $\mathrm{L}_{2}=2,2^{\prime}-\left(4,4^{\prime}-\left(2,2^{\prime}\right.\right.$-oxybis(ethane-2,1-diyl)bis(oxy))bis(4,1phenylene) $)$ bis $\left(1 H\right.$-imidazo[4,5-f][1,10]phenanthroline), $\mathrm{L}_{3}=1,2$-bis(2-(4(1H-imidazo[4,5-f][1,10]phenanthrolin-2-yl)phenoxy)ethoxy) ethane ${ }^{[11]}$ (see Table 1). Therefore, the evident hypochromisms observed for the UV and/or visible absorption bands of the ruthenium complex studied in this paper could only exclude the electrostatic DNA binding mode.

The intrinsic binding constant $K_{\mathrm{b}}$, which illustrates the binding strength of the complex with DNA quantitatively, was derived according to Eq. (1): ${ }^{\text {:33] }}$

$$
\begin{aligned}
& \left(\varepsilon_{\mathrm{a}}-\varepsilon_{\mathrm{f}}\right) /\left(\varepsilon_{\mathrm{b}}-\varepsilon_{\mathrm{f}}\right)=\left(b-\left(b^{2}-2 K_{\mathrm{b}}{ }^{2} C_{\mathrm{t}}[\mathrm{DNA}] / s\right)^{1 / 2}\right) /\left(2 K_{\mathrm{b}} C_{\mathrm{t}}\right) \\
& \mathrm{b}=1+K_{\mathrm{b}} C_{\mathrm{t}}+K_{\mathrm{b}}[\mathrm{DNA}] / 2 s
\end{aligned}
$$

where [DNA] is the concentration of DNA in nucleotides, $\varepsilon_{\mathrm{a}}, \varepsilon_{\mathrm{f}}$ and $\varepsilon_{\mathrm{b}}$ are the apparent, free and bound ruthenium complex extinction coefficients, respectively, $s$ is the binding site size, and $C_{\text {t }}$ is the total ruthenium complex concentration. As shown in the inset of Fig. 1, by monitoring the changes in absorbance at $285 \mathrm{~nm}$ through a plot of $(\varepsilon-\varepsilon) /(\varepsilon-\varepsilon)$ versus [DNA], the $K$ of the complex was obtained to be $2.68 \times 10^{6} \mathrm{M}^{-1}$, which is comparable to $1.61 \times 10^{6} \mathrm{M}^{-1}$ for the DNA groove binder of $\left[\left\{(\mathrm{bpy})_{2} \mathrm{Ru}\right\}_{2}(4-\mathrm{azo})\right]^{4+},{ }^{[21]}$ but smaller than $1.7 \times 10^{7} \mathrm{M}^{-1}, 3.3 \times 10^{8} \mathrm{M}^{-1}$ and $1.1 \times 10^{7} \mathrm{M}^{-1}$ for the DNA

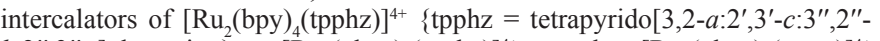
$\left.h: 2^{\prime \prime}, 3^{\prime \prime}-j\right]$ phenazine $\}, \quad\left[\operatorname{Ru}_{2}(\text { phen })_{4}(\text { tpphz })\right]^{4+}$ and $\left[\operatorname{Ru}_{2}(\text { phen })_{4}(\operatorname{tatpp})\right]^{4+}$

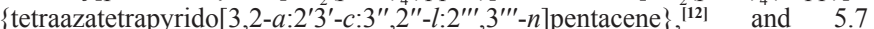
$\times 10^{7} \mathrm{M}^{-1}, 7.5 \times 10^{7} \mathrm{M}^{-1}$ and $9.5 \times 10^{7} \mathrm{M}^{-1}$ for the threading intercalators of $\left[\mathrm{Ru}_{2}(\text { bpy) }(\mathrm{L})]^{4+}\left(\mathrm{L}=\mathrm{L}_{1}, \mathrm{~L}_{2} \text { or } \mathrm{L}_{3}\right)^{[11]}\right.$ as illustrated in Table 1. So it can be speculated that the complex $\left[\mathrm{Ru}_{2}(\mathrm{bpy})_{4}(\text { bip-phenol) }]^{4+}\right.$ bond to DNA probably through groove mode.

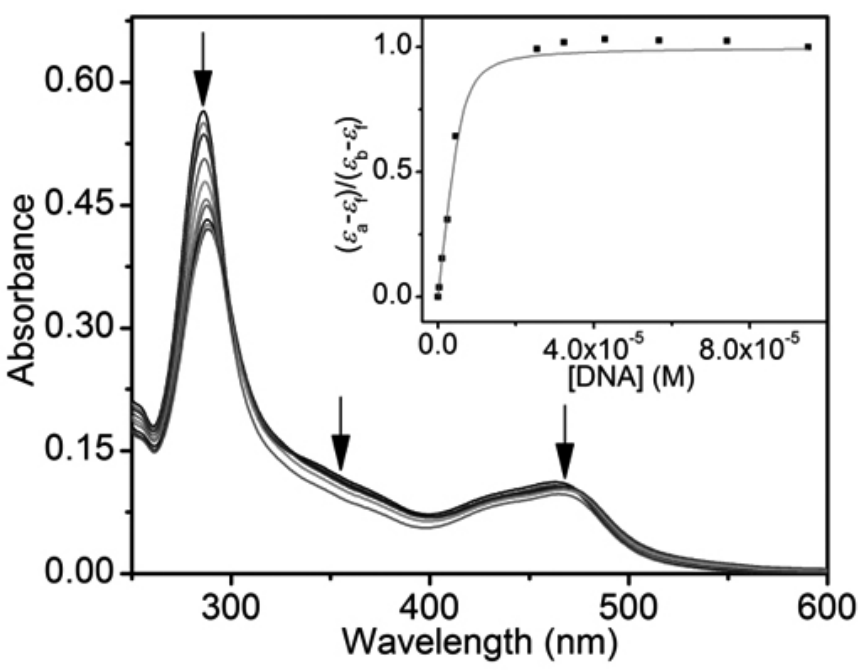

Fig. 1: Absorption spectra of the ruthenium complex $(3.4 \mu \mathrm{M})$ with increasing concentrations of DNA $(0-175 \mu \mathrm{M})$. Inset: plot of $\left(\varepsilon_{\mathrm{a}}-\varepsilon_{\mathrm{f}}\right) /\left(\varepsilon_{\mathrm{b}}-\varepsilon_{\mathrm{f}}\right) v_{s}$. [DNA] and the nonlinear fit. 
Table 1. Comparisons of DNA binding parameters.

\begin{tabular}{|c|c|c|c|c|}
\hline Complex & $H / \%(\lambda / \mathrm{nm})$ & $K_{\mathrm{b}}\left(\mathrm{M}^{-1}\right)$ & Binding mode & Ref. \\
\hline$\left[\mathrm{Ru}_{2}(\mathrm{bpy})_{4}(\text { bip-phenol })\right]^{4+}$ & $25(285), 22(355), 11(465)$ & $2.5 \times 10^{6}$ & groove binding & this work \\
\hline$\left[\left\{(\mathrm{bpy})_{2} \mathrm{Ru}\right\}_{2}(4-\mathrm{azo})\right]^{4+}$ & $<10(438), 17(558)$ & $1.61 \times 10^{6}$ & groove binding & $\mathbf{2 1}$ \\
\hline$\Delta \Delta-\left[\mathrm{Ru}_{2}(\mathrm{bpy})_{4}(\mathrm{bdptb})\right]^{4+}$ & $40(492.5)$ & - & groove binding & $\mathbf{3 2}$ \\
\hline$\left[\mathrm{Ru}_{2}(\mathrm{phen})_{4}\left(\mathrm{mbpibH}_{2}\right)\right]^{4+}$ & $47.1(264), 9.2(460)$ & - & intercalation & $\mathbf{1 3}$ \\
\hline$\left[\mathrm{Ru}_{2}(\mathrm{bpy})_{4}(\mathrm{ebipcH})\right]^{4+}$ & $37(288 \mathrm{~nm})$ & $1.3 \times 10^{6}$ & intercalation & $\mathbf{1 2}$ \\
\hline$\left[\mathrm{Ru}_{2}(\mathrm{bpy})_{4}(\mathrm{tpphz})\right]^{4+}$ & - & $1.1 \times 10^{7}$ & intercalation & $\mathbf{1 2}$ \\
\hline$\left[\mathrm{Ru}_{2}(\mathrm{phen})_{4}(\mathrm{tpphz})\right]^{4+}$ & - & $3.3 \times 10^{8}$ & intercalation & $\mathbf{1 2}$ \\
\hline$\left[\mathrm{Ru}_{2}(\mathrm{phen})_{4}(\mathrm{tatpp})\right]^{4+}$ & - & $1.1 \times 10^{7}$ & intercalation & $\mathbf{1 1}$ \\
\hline$\left[\mathrm{Ru}_{2}(\mathrm{bpy})_{4}\left(\mathrm{~L}_{1}\right)\right]^{4+}$ & $45(287), 5(465)$ & $5.7 \times 10^{7}$ & threading intercalation & $\mathbf{1 1}$ \\
\hline$\left[\mathrm{Ru}_{2}(\mathrm{bpy})_{4}\left(\mathrm{~L}_{2}\right)\right]^{4+}$ & $38(285), 5(465)$ & $7.5 \times 10^{7}$ & threading intercalation & $\mathbf{1 1}$ \\
\hline$\left[\mathrm{Ru}_{2}(\mathrm{bpy})_{4}\left(\mathrm{~L}_{3}\right)\right]^{4+}$ & $47(286), 5(465)$ & $9.5 \times 10^{7}$ & threading intercalation & $\mathbf{1 1}$ \\
\hline
\end{tabular}

\subsection{Emission spectra}

Barton have reported that $\left[\mathrm{Ru}(\mathrm{bpy})_{2}(\mathrm{dppz})\right]^{2+}$ and $\left[\mathrm{Ru}(\mathrm{phen})_{2}(\mathrm{dppz})\right]^{2+}$ exhibited intense luminescence in the presence of double helical DNA with $>10^{4}$-fold enhancements in luminescence intensity. ${ }^{1}$ It was found that not only intercalators but also groove binders could be induced significant manifestation of emission intensity by interacting with DNA strongly. For example, except for DNA intercalators of $\left[\mathrm{Ru}(\mathrm{bpy})_{2}(\mathrm{dppz})\right]^{2+}$ and $\left[\mathrm{Ru}(\mathrm{phen})_{2}(\mathrm{dppz})\right]^{2+}$ with the DNA-induced luminescence switching behaviors, the increment factors of emission intensity of the bound complex to the free form were reported to be 24 for DNA intercalator of $\mathrm{EB},{ }^{[34]}$ and 140 and 26 for DNA groove binders of Hoechst $33258^{[34]}$ and $\left[\mathrm{Ru}(\mathrm{phen})_{2}(\mathrm{Hcdpq})\right]^{2+}\{\mathrm{Hcdpq}=2$-carboxyldipyrido[3,2$\left.f: 2^{\prime}, 3^{\prime}-h\right]$ quinoxaline $\}$, respectively. ${ }^{[35]}$ The effects of successive additions of DNA on the emission spectra of $\left[\mathrm{Ru}_{2}(\text { bpy })_{4} \text { (bip-phenol) }\right]^{4+}$ are illustrated in Fig. 2 (a) and (b). It is clear that in the absence of DNA, the complex in neutral aqueous solution emitted weak luminescence centered at $594 \mathrm{~nm}$ upon visible light excitation at $460 \mathrm{~nm}$. While upon successive additions of DNA, the luminescence of the complex revived sharply by a factor of $6.3(I / I)$ at saturation binding ratio of $[\mathrm{DNA}] /[\mathrm{Ru}] \approx 51$, which was greater than those of $3,1.4,2.08,2.36,1.68$ previously reported for dinuclear complexes of $\left[\mathrm{Ru}_{2}(\text { phen })_{4}\left(\mathrm{mbpibH}_{2}\right)\right]^{4+},{ }^{[13]}\left[(\mathrm{bpy})_{2} \mathrm{Ru}(\mu \text {-bipp}) \mathrm{Ru}(\mathrm{bpy})_{2}\right]^{4+}\{$ bipp $=2,9$-bis(2imidazo[4,5-f][1,10]phenanthroline)-1,10-phenanthroline $\}^{[36]}$ and $\left[(\text { phen })_{2}\right.$ $\mathrm{Ru}\left(\text { Mebipy)-( } \mathrm{CH}_{2}\right)_{\mathrm{n}}$-(bipyMe)Ru(phen $\left.)_{2}\right]^{4+}\{\mathrm{n}=5,7,10$; Mebpy- = 4-methyl$2,2^{\prime}$-bipyridine- $\left.4^{\prime}-\right\},{ }^{[37]}$ respectively, but much lower than those of $>60$ found for $\left[\mathrm{Ru}_{2}(\mathrm{bpy})_{4}(\mathrm{tpphz})\right]^{4+}$ and $\left[\mathrm{Ru}_{2}(\text { phen })_{4}(\mathrm{tpphz})\right]^{4+} \cdot{ }^{[12]}$ Comparing to the wellstudied $\left[\mathrm{Ru}(\mathrm{bpy})_{2}(\mathrm{dppz})\right]^{2+}$ and $\left[\mathrm{Ru}(\mathrm{phen})_{2}(\mathrm{dppz})\right]^{2+}$, the complex may not be considered as DNA molecular "light switch". However, the large emission enhancement factor observed for the complex implies that the complex had a strong interaction with DNA and was efficiently protected from the accessibility of solvent water, resulting in a decrease of non-irradiative vibration relaxation and accordingly enhanced emission. The $K_{\mathrm{b}}$ value of the complex could also be obtained by fitting the fractional changes in emission intensities, $\left(I_{\mathrm{a}}-I_{\mathrm{f}}\right) /\left(I_{\mathrm{b}}\right.$ $I_{\mathrm{f}}$ ), as a function of DNA concentrations according to the Bard-Torp-Murphy Eq. (2) (Fig. 2 (c)): ${ }^{[38]}$

$$
\begin{aligned}
& \left(I_{\mathrm{a}}-I_{\mathrm{f}}\right) /\left(I_{\mathrm{b}}-I_{\mathrm{f}}\right)=\left(b-\left(b^{2}-2 K_{\mathrm{b}}{ }^{2} C_{\mathrm{t}}[\mathrm{DNA}] / s\right)^{1 / 2}\right) /\left(2 K_{\mathrm{b}} C_{\mathrm{t}}\right) \\
& b=1+K_{\mathrm{b}} C_{\mathrm{t}}+K_{\mathrm{b}}[\mathrm{DNA}] / 2 s
\end{aligned}
$$

where $I_{\mathrm{a}}, I_{\mathrm{f}}$ and $I_{\mathrm{b}}$ are fluorescence intensity at a given DNA concentration, the complex free in solution and the complex fully bound to DNA, respectively; $C_{\mathrm{t}}$ is the total ruthenium complex concentration, [DNA] is the DNA concentration in nucleotides, and $s$ is the binding site size. Fortunately, the $K_{\mathrm{b}}$ and $s$ values were derived to be $4.91 \times 10^{6} \mathrm{M}^{-1}$ and 4.19 , respectively. The large DNA binding constant which is consistent with the results of UV-Vis absorption titrations, also indicates strong binding of the complex to DNA.
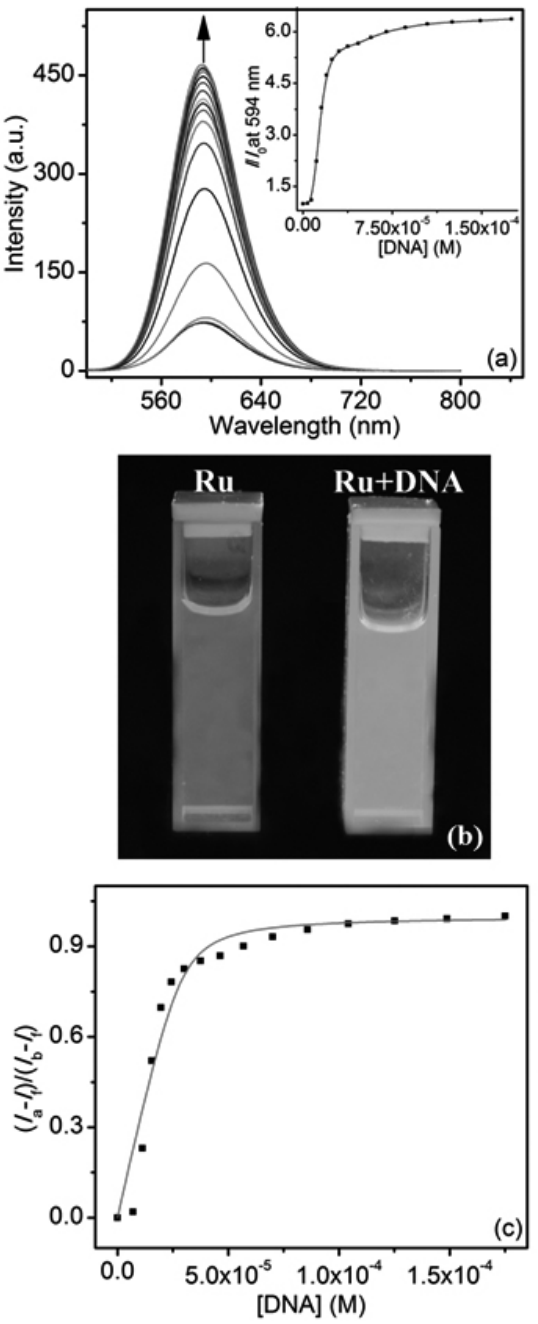

Fig. 2: (a) Fluorescence titration of the ruthenium complex $(3.4 \mu \mathrm{M})$ with DNA $(0-175 \mu \mathrm{M})$. Inset: plot of $I / I_{0} v s$. [DNA] and the best fit curve. (b) Image of "DNA light switch" behavior of the ruthenium complex. Left: $[\mathrm{Ru}]=3.4$ $\mu \mathrm{M}$; right: $[\mathrm{Ru}]=3.4 \mu \mathrm{M},[\mathrm{DNA}]=175 \mu \mathrm{M}$. (c) Plot of $\left(I-I_{0}\right) /\left(I_{\mathrm{b}}-I_{0}\right) v s$. [DNA] and the nonlinear fitting. 
Table 2. Luminescence properties of the ruthenium complexes in the presence of DNA.

\begin{tabular}{|c|c|c|}
\hline Complex & $I / I_{0}^{\mathrm{a}}$ & Ref. \\
\hline$\left[\mathrm{Ru}_{2}(\mathrm{bpy})_{4}(\text { bip-phenol) }]^{4+}\right.$ & 6.3 & this work \\
\hline$\left[\mathrm{Ru}_{2}(\text { phen })_{4}\left(\mathrm{mbpibH}_{2}\right)\right]^{4+}$ & 3 & 13 \\
\hline$\left[(\text { bpy })_{2} \operatorname{Ru}(\mu \text {-bipp }) \operatorname{Ru}(\text { bpy })_{2}\right]^{4+}$ & 1.4 & 36 \\
\hline $\begin{array}{l}{\left[(\text { phen })_{2}-\mathrm{Ru}(\text { Mebipy })-\left(\mathrm{CH}_{2}\right)_{5}-\right.} \\
\left.\quad(\text { bipyMe }) \mathrm{Ru}(\text { phen })_{2}\right]^{4+}\end{array}$ & 2.08 & 37 \\
\hline $\begin{array}{l}{\left[(\text { phen })_{2}-\mathrm{Ru}(\text { Mebipy })-\left(\mathrm{CH}_{2}\right)_{7}-\right.} \\
\left.\quad(\text { bipyMe }) \mathrm{Ru}(\text { phen })_{2}\right]^{{ }^{+}}\end{array}$ & 2.36 & 37 \\
\hline $\begin{array}{l}{\left[(\text { phen })_{2}-\mathrm{Ru}(\text { Mebipy })-\left(\mathrm{CH}_{2}\right)_{10}-\right.} \\
\left.\quad \text { (bipyMe)Ru(phen })_{2}\right]^{++}\end{array}$ & 1.68 & 37 \\
\hline$\left[\mathrm{Ru}_{2}(\mathrm{bpy})_{4}(\mathrm{tpphz})\right]^{4+}$ & $>60$ & 12 \\
\hline$\left[\mathrm{Ru}_{2}(\text { phen })_{4}(\mathrm{tpphz})\right]^{4+}$ & $>60$ & 12 \\
\hline$\left[\mathrm{Ru}(\mathrm{bpy})_{2}(\mathrm{dppz})\right]^{2+}$ & $>10^{4}$ & 1 \\
\hline$\left[\mathrm{Ru}(\text { phen })_{2}(\mathrm{dppz})\right]^{2+}$ & $>10^{4}$ & 1 \\
\hline $\mathrm{EB}$ & 24 & 34 \\
\hline Hoechst 33258 & 140 & 34 \\
\hline$\left[\operatorname{Ru}(\text { phen })_{2}(\text { Hcdpq })\right]^{2+}$ & 26 & 36 \\
\hline
\end{tabular}

a $I / I_{0}$ refers to the luminescence of the ruthenium complex in the presence of saturating amounts of DNA $(I)$ compared to that in the absence of DNA $\left(I_{0}\right)$.

\subsection{Luminescence quenching by $\left[\mathrm{Fe}(\mathrm{CN})_{6}\right]^{4-}$}

Steady-state emission quenching experiment using $\mathrm{K}_{4}\left[\mathrm{Fe}(\mathrm{CN})_{6}\right]$ as the quencher is a sensitive and convenient means to shed light on the DNA binding properties of ruthenium complex. It should be pointed out that $\left[\mathrm{Fe}(\mathrm{CN})_{6}\right]^{4-}$ could significantly quenches the emission of the positively charged ruthenium complex which is free in solution, but weakly quenches the emission of the ruthenium complex which is tightly bound to DNA, as the highly anionic quencher $\left[\mathrm{Fe}(\mathrm{CN})_{6}\right]^{4-}$ is expected to be repelled by the negative DNA phosphate backbone. Therefore, a more deeply DNA-bound cationic ruthenium complex could be more protected from quenching than loosely or shallowly bound complex (e.g. partially intercalating complex). However, it is noteworthy that the absence of quenching by $\left[\mathrm{Fe}(\mathrm{CN})_{6}\right]^{4-}$ is not a proof of DNA intercalation.

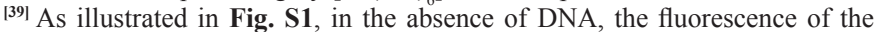
complex $\left[\mathrm{Ru}_{2}(\text { bpy })_{4}(\text { bip-phenol) }]^{4+}\right.$ was efficiently quenched by $\left[\mathrm{Fe}(\mathrm{CN})_{6}\right]^{4-}$, resulting in a linear-Volmer plot with a Stern-Volmer quenching constant $K_{\mathrm{sv}}$ of $9.7 \times 10^{3} \mathrm{M}^{-1}$ according to Stern-Volmer equation: $I_{0} / I=1+K_{\mathrm{sv}}[\mathrm{Q}]$, in which $I_{0}$ and $I$ are the emission intensities in the absence and the presence of $\left[\mathrm{Fe}(\mathrm{CN})_{6}\right]^{4-}$, respectively; $[\mathrm{Q}]$ is the concentration of $\left[\mathrm{Fe}(\mathrm{CN})_{6}\right]^{4-}$. In contrast, the slope of the plot was remarkably decreased to $67 \mathrm{M}^{-1}$ in the presence of DNA, suggesting that the complex was protected by DNA from accessibility of $[\mathrm{Fe}(\mathrm{CN})]^{4-}$ and thus was quenched to a lesser extent. A ratio of the $K$ value derived in the absence of the DNA to that derived in the presence of the DNA, $R$, was found to be 145 for the complex. The large $R$ value also reflects the strong DNA binding affinity of the complex.

\subsection{Competitive Binding to the DNA with Ethidium Bromide}

The competitive binding experiment based on displacement of the typical intercalating drug ethidium bromide (EB) from ct-DNA-EB adduct could afford further information about the DNA binding properties of the ruthenium complex. As well known, the free EB in aqueous solution is very weakly emissive because the surrounding water molecules quench its fluorescence. ${ }^{[38,40]}$ However, the fluorescence of EB would be sharply increased by a factor of 20 after binding to DNA with two modes, namely intercalation and groove binding. It was previously reported that the enhanced fluorescence of the DNA-EB complex could be quenched by the addition of a second DNA binder which is either an intercalator or a groove binder, such as intercalators of $\left[\mathrm{Ru}_{2}(\mathrm{bpy})_{4} \mathrm{~L}\right]^{4+[11]}$ and groove binder of $\left[\mathrm{Ru}(\mathrm{phen})_{2}(\mathrm{Hcdpq})\right]^{2+}$. $^{[35]}$ It is noteworthy that as excited at $\lambda_{\text {ex }}=537 \mathrm{~nm}$, not only free EB but also the ruthenium complex in the free and DNA bound forms are negligibly weakly emissive, which facilitates the monitoring of the extent of the EB that is displaced from DNA bound EB. As shown in Fig. S2, a remarkable reduction in emission intensities by $93 \%$ was observed with the successive addition of the complex $\left[\mathrm{Ru}_{2}(\text { bpy })_{4} \text { (bip-phenol) }\right]^{4+}(51 \mu \mathrm{M})$ to EB-DNA system, and the significant decrease in emission intensities is suggestive of strong interaction of the complex with DNA. In order to further illustrate the DNA binding affinity of the complex, the competitive binding model was used to calculate the apparent DNA binding constant according equation: $K_{\mathrm{app}}=K_{\mathrm{BB}}\{[\mathrm{EB}] /[\mathrm{Ru}]\}_{50 \%}$, in which $K_{\text {app }}$ is the apparent DNA binding constant of the ruthenium complex, $K_{\mathrm{FB}}$ is the DNA binding constant of EB, $[\mathrm{EB}]_{50 \%}$ and $[\mathrm{Ru}]_{50 \%}$ are the EB and ruthenium complex concentrations at $50 \% \mathrm{~EB}$ replacement. ${ }^{38,40]}$ The inset of Fig. S2 revealed that $50 \%$ of EB molecules were displaced by the complex at a concentration ratio of $[\mathrm{Ru}] /[\mathrm{EB}]=0.46$ (the influence of ruthenium complex at $537 \mathrm{~nm}$ was subtracted already). By employing a known DNA binding constant value of $\mathrm{EB}, K_{\mathrm{EB}}=1.25 \times 10^{6} \mathrm{M}^{-1},{ }^{[38,40]}$ the value of the apparent DNA binding constant for the complex, $K$, was derived to be $2.70 \times 10^{6} \mathrm{M}^{-1}$, which agrees well with the $K_{\mathrm{b}}$ values of $2.68 \times 10^{6} \mathrm{M}^{-1}$ and $4.91 \times 10^{6} \mathrm{M}^{-1}$ derived from UVVis and emission spectral titration data, respectively. The large DNA binding constant of the complex indicates its high binding strength to DNA obviously.

3.5 Thermal denaturation of DNA

Since double-stranded DNA would gradually dissociate to single strands when temperature increases, the DNA melting study by using a temperaturecontrolling programmer was carried out. The thermal behavior of DNA in the presence of ruthenium complex could provide information about the ability of the complex to stabilize the double strands of DNA and give hints on the DNA binding mode by characterizing the helix-to-coil transition temperature. Because the extinction coefficient of DNA bases at $260 \mathrm{~nm}$ in the singlestranded form is much higher than in the double helical form, melting of the helix would generate a hypochromic effect in the absorption at this wavelength. ${ }^{[41-44]}$ In order to identify this transition process, the melting temperature $T_{\mathrm{m}}$, which is defined as the temperature where half of the total base pairs are unpaired, is usually introduced. The melting curves of DNA in the absence and presence of the complex $\left[\mathrm{Ru}_{2}(\mathrm{bpy})_{4} \text { (bip-phenol) }\right]^{4+}$ are presented in Fig. 3. Here, the thermal denaturation of free DNA occurred with a $T_{\mathrm{m}}{ }^{0}$ of $56^{\circ} \mathrm{C}$ under our experimental conditions. The observed melting temperatures $\left(T_{\mathrm{m}}\right)$ in the presence of the ruthenium complex were 63,69 and $76{ }^{\circ} \mathrm{C}$ at concentration ratios of $[\mathrm{Ru}] /[\mathrm{DNA}]=1: 40,1: 20$ and $1: 10$, respectively, indicating the increased stability of the double helix as the complex bound to DNA. It is clear that the complex raised the $T$ values by $20{ }^{\circ} \mathrm{C}(\Delta T)$ at $[\mathrm{Ru}] /[\mathrm{DNA}]=1: 10$ compared to that of pure DNA sample, which is much larger than $\Delta T_{\mathrm{m}}<2{ }^{\circ} \mathrm{C}$ for the DNA in the presence of electrostatic DNA binder of $\left[\mathrm{Ru}(\mathrm{bpy})_{3}\right]^{\mathrm{m}+[45]}$ and $\Delta T_{\mathrm{m}}=7.7^{\circ} \mathrm{C}$ and $9{ }^{\circ} \mathrm{C}$ for DNA partial intercalators of $\left[\mathrm{Ru}(\text { phen })_{2} \text { (pyni) }\right]^{2+}$ $\left\{\text { pyni }=2-\left(2^{\prime} \text {-pyridyl)naphthoimidazole }\right)\right\}^{[46]}$ and $[\operatorname{Ru}(\operatorname{dipn})(\text { pat })]^{2+}\{$ dipn $=$ $\mathrm{N}$-(3-aminopropyl)propane-1,3-diamine, pat = 9-(1,10-phenanthrolin-2-yl) acenaphtho[1,2-e][1,2,4]triazine $)\},{ }^{[47]}$ but comparable to $\Delta T_{\mathrm{m}}>15{ }^{\circ} \mathrm{C}$ that previously reported for DNA threading intercalators of $\left[\mathrm{Ru}_{2}(\text { bpy })_{4} \mathrm{~L}\right]^{4+[11]}$ and DNA groove binder of azo based complex $\left[\left\{(\mathrm{bpy}){ }_{2} \mathrm{Ru}\right\}_{2}(4-\mathrm{azo})\right]^{4+}$. $^{[21]}$ Therefore, the electrostatic binding mode can be eliminated for the complex; the relatively high $\Delta T_{\mathrm{m}}$ value is most likely indicative of a groove binding mode or an intercalation binding mode.

The DNA intrinsic binding constant of the complex at melting temperature was determined by McGhee equation (Eq. (3)): $:^{[48,49]}$

$$
1 / T_{\mathrm{m}}^{0}-1 / T_{\mathrm{m}}=\left(R / \Delta H_{\mathrm{m}}\right) \ln (1+K L)^{1 / n}
$$

where $T^{0}$ is melting point of DNA alone, $T$ is the melting temperatures of DNA in the presence of ruthenium complex, $\Delta H_{\mathrm{m}}$ is the enthalpy of DNA melting $\left(\Delta H_{\mathrm{m}}=6.9 \mathrm{kcal} \mathrm{mol}^{-1}\right),{ }^{[48,49]} R$ is the gas constant, $K$ is the DNA binding constant at $T_{\mathrm{m}}, L$ is the free ruthenium complex concentration (approximated by the total complex concentration), and $n$ is the size of the binding site. By taking $n=4.19$ that obtained from the luminescence spectra titration experiment, the binding constant $K$ was derived to be $2.32 \times 10^{6} \mathrm{M}^{-1}$ at $76^{\circ} \mathrm{C}$, indicating that the complex still displayed high binding affinity at the melting point of DNA. The changes in the standard enthalpy $\left(\Delta H^{0}\right)$, standard free energy $\left(\Delta G_{\mathrm{T}}{ }^{0}\right)$ and standard entropy $\left(\Delta S^{0}\right)$ of binding for the complex to DNA were determined from the van't Hoff equation, Eqs. (4)-(6): ${ }^{[48,49]}$

$$
\begin{aligned}
& \left.\ln \left(K_{1} / K_{2}\right)=\left(\Delta H^{0} / R\right)\left(T_{1}-T_{2}\right) / T_{1} T_{2}\right] \\
& \Delta G_{\mathrm{T}}^{0}=-R T \ln K
\end{aligned}
$$$$
\Delta G_{\mathrm{T}}{ }^{0}=\Delta H^{0}-T \Delta S^{0}
$$

where $K_{1}$ and $K_{2}$ are the DNA binding constants of the complex at $T_{1}$ and $T_{2}$, respectively. By using a $K_{1}$ value of $4.91 \times 10^{6} \mathrm{M}^{-1}\left(T_{1}=298.15 \mathrm{~K}\right)$ and a $K_{2}$ value of $2.32 \times 10^{6} \mathrm{M}^{-1}\left(T_{2}=349.15 \mathrm{~K}\right)$, the $\Delta H^{0}, \Delta G^{0}$, and $T \Delta S^{0}$ at $25^{\circ} \mathrm{C}$ were 
derived to be $-12.7 \mathrm{~kJ} \mathrm{~mol}^{-1},-38.2 \mathrm{~kJ} \mathrm{~mol}^{-1}$ and $85.5 \mathrm{~J} \mathrm{~mol}^{-1} \mathrm{~K}^{-1}$, respectively. The negative binding free energy change suggests that the sum of the free energies of free complex and the DNA is higher than that of their adduct and binding of the complex to DNA is energetically highly favorable at $298.15 \mathrm{~K}$, and the binding reaction of the complex is both enthalpically and entropically driven in view of large negative enthalpy values and positive entropy values.

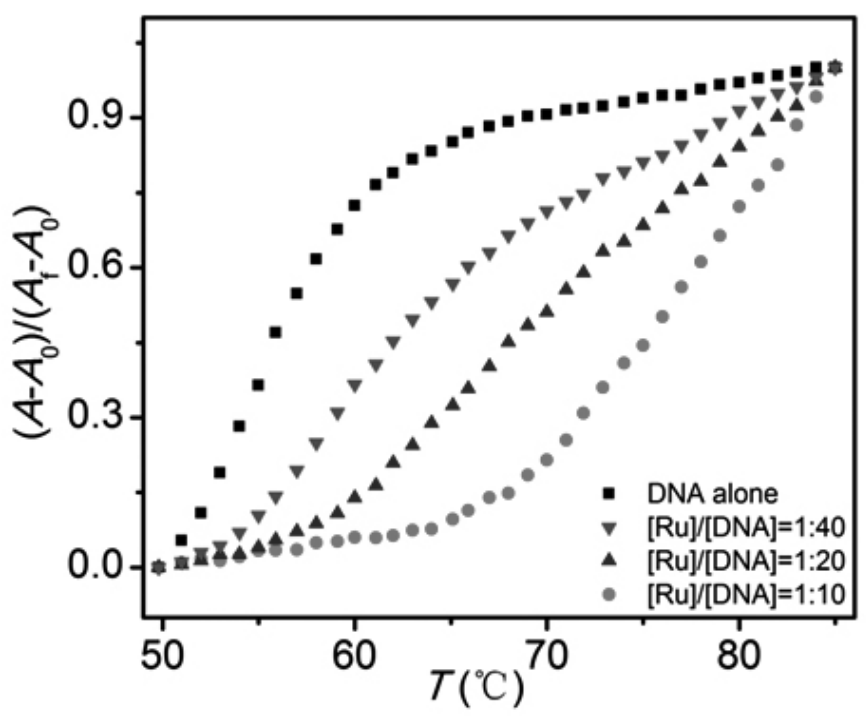

Fig. 3: Thermal denaturation curves of DNA $(50 \mu \mathrm{M})$ at different ruthenium complex concentrations of $[\mathrm{Ru}] /[\mathrm{DNA}]=1 / 10,1 / 20,1 / 40$, and DNA alone.

\subsection{Reverse salt effect}

The ruthenium complex has a dipositive charge in neutral aqueous solution, so it could be expected that the interaction between the ruthenium complex and DNA would be influenced by such factors as the presence of other cation or the ionic strength of the solution. ${ }^{[50]}$ The sensitivity of the DNA binding constants of the ruthenium complexes to ionic strength is expected to decrease in the order of the binding modes, electrostatic $>$ groove $>$ intercalative, which could give insight into the DNA binding modes in quantitative manners. As the polyelectrolyte theories reported by Record et al. are strictly applicable to salt concentrations of lower than $0.100 \mathrm{M}$, the salt concentrations of $0.025,0.050$ 0.075 and $0.100 \mathrm{M}$ were selected in this study. The changes in UV-Vis spectra of $\left[\mathrm{Ru}_{2}(\mathrm{bpy})_{4}(\text { bip-phenol) }]^{4+}\right.$ upon successive additions of DNA at the salt concentrations of $0.025,0.075$ and $0.100 \mathrm{M}$ are shown in Fig. S3-5. According

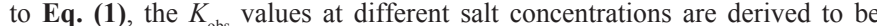
$1.72 \times 10^{7} \mathrm{M}^{-1}$ for $0.025 \mathrm{M} \mathrm{NaCl}, 2.68 \times 10^{6} \mathrm{M}^{-1}$ for $0.050 \mathrm{M} \mathrm{NaCl}$ (see Fig. 1), $7.66 \times 10^{5} \mathrm{M}^{-1}$ for $0.075 \mathrm{M} \mathrm{NaCl}$, and $3.45 \times 10^{5} \mathrm{M}^{-1}$ for $0.100 \mathrm{M} \mathrm{NaCl}$. A plot of $\log K_{\mathrm{b}}$ against $\log \left[\mathrm{Na}^{+}\right]$for the binding of the complex to DNA is given in Fig. S6. Clearly, the DNA binding constants decreased with increasing salt concentrations, which is due to stoichiometry release of sodium ion following the binding of the complex to DNA. This implies that the electrostatic interaction is involved in the DNA binding event. The polyelectrolyte theory could be used to evaluate the electrostatic and nonelectrostatic contribution to the binding free energy changes. The slope of the linear fitting of Fig. S6 is equal to $S K$ in Eq. (7): ${ }^{[48,49]}$

$$
S K=-Z \psi=\delta \log K_{\mathrm{obs}} / \delta \log \left[\mathrm{Na}^{+}\right]
$$

where $Z$ is the charge on the ruthenium complex and $\psi$ is the fraction of counterions associated with each DNA phosphate $(\psi=0.88$ for doublestranded B-form DNA). The binding free energy can be calculated based on the standard Gibbs Eq. (8): ${ }^{[48,49]}$

$$
\begin{aligned}
& \Delta G_{\mathrm{obs}}=-R T \ln K_{\mathrm{obs}} \\
& \Delta G_{\mathrm{pe}}=(S K) R T \ln \left[\mathrm{Na}^{+}\right] \\
& \Delta G_{\mathrm{t}}=\Delta G_{\mathrm{obs}}-\Delta G_{\mathrm{pe}}
\end{aligned}
$$

Electrostatic $\left(G_{\mathrm{pe}}\right)$ and nonelectrostatic $\left(G_{\mathrm{t}}\right)$ portions of the free energy can be calculated from Eqs. (9) and (10), respectively. A $S K$ value of -2.6 was obtained by linear fitting, and a charge $Z$ of 2.95 derived is smaller than four positive charges carried by the complex. The $\Delta G_{t}$ and $\Delta G$ at $0.050 \mathrm{M} \mathrm{NaCl}$ were obtained to be -17.2 and $-19.3 \mathrm{~kJ} \cdot \mathrm{mol}^{-1}$, respectively, indicating that the nonelectrostatic contribution to the total binding energy $\left(\Delta G_{t} / \Delta G_{\text {obs }} \times 100 \%\right)$ is $43 \%$, which is nearly equal to the electrostatic portion. The observed significant electrostatic contributions to the free energy of the complex is not surprising, as the dinuclear ruthenium complex is highly and densely (two $\mathrm{Ru}$ (II) ions are close to each other) charged, similar to the $47 \%$ contributions to $\Delta G$ from nonelectrostatic binding free energy change $\Delta G_{\mathrm{t}}$ for previously reported DNA intercalator of dinuclear complex $\left[\mathrm{Ru}_{2}(\mathrm{bpy})_{4}\left(\mathrm{ebipcH}_{2}\right)\right]^{4+}$. It is evident from Table 3 that the percentage of nonelectrostatic contributions of the complex are much smaller than $63 \%-85 \%$ for proven classical DNA intercalators of $\mathrm{EB},{ }^{[51]}$ daynomycin $^{[51]}$ and $\left[\mathrm{Ru}(\mathrm{phen}(\mathrm{dppz})]^{2+},{ }^{[52]}\right.$ but much greater than $32 \%$ for electrostatic DNA binder of [(bpy) $\left.\mathrm{Ru}(\mathrm{Mebpy})\left(\mathrm{CH}_{2}\right)_{7}(\mathrm{Mebpy}) \mathrm{Ru}(\mathrm{bpy})_{2}\right]^{4+},{ }^{[51]}$ while comparable to $47 \%$ for DNA intercalator of $\left[\mathrm{Ru}_{2}(\mathrm{bpy})_{4}\left(\mathrm{ebipcH}_{2}\right)\right]^{4+}$ as mentioned above, ${ }^{[15]}$ and $55-57 \%$ for groove binders of $\left[\mathrm{Ru}(\mathrm{phen})_{2}(\mathrm{Hcdpq})\right]^{+[35]}$ and $\left[\mathrm{Ru}(\mathrm{phen})_{3}\right]^{2+} \cdot{ }^{[53]}$ The above results give a signature that the complex $\left[\mathrm{Ru}_{2}(\text { bpy })_{4}(\text { bip-phenol })\right]^{4+}$ is probably a DNA intercalator or a groove DNA binder.

\subsection{Viscosity Measurements}

The optical studies cannot provide sufficient evidence to support the binding mode, while the hydrodynamic measurements, such as viscosity and sedimentation, are critical tests for probing the nature of the interaction of the complex with DNA in the absence of crystallographic structural data. It is popularly accepted that classical intercalation of moieties into DNA causes a significant increase in the viscosity of a DNA solution because of an increase in the separation of the base pairs at the intercalation site and hence, an increase in the overall molecular length of the DNA. In contrast, partial intercalation or non-classic intercalation of the metal complex would bend. or kink the DNA helix, shortening the DNA effective length, and reducing DNA viscosity accordingly. Complexes that interact with DNA in the electrostatic or groove mode have distinctly less pronounced or no effects on the viscosity of DNA. ${ }^{[4,54]}$ Fig. 4 shows the changes of DNA viscosity as the complex $\left[\mathrm{Ru}_{2}(\mathrm{bpy})_{4} \text { (bip-phenol) }\right]^{4+}$ was successively added together with those caused by additions of intercalator EB. As expected, the relative viscosities of DNA increased steadily on increasing the amounts of EB due to the intercalation mode. However, successive additions of the complex produced slightly declined DNA viscosities, indicating that it bound to the DNA via electrostatic or groove mode. Since the aforementioned optical spectroscopy techniques including the absorption spectra titration, the thermal denaturation and the reverse salt effect have suggested the groove binding or intercalating of the complex to DNA, thus we attributed the DNA viscosity behaviors in the presence of the complex to groove binding mode, which is similar to the reported DNA groove binders of $\left[\mathrm{Ru}(\text { phen })_{3}\right]^{2+},{ }^{[53]}\left[\mathrm{Ru}(\mathrm{phen})_{2}(\mathrm{Hcdpq})\right]^{+},{ }^{[35]}$ $\left[\mathrm{Ru}_{2}(\mathrm{bpy})_{4}(\mathrm{btb})\right]^{4+} \quad\left\{\mathrm{btb}=2,2^{\prime}\right.$-bis $(1,2,4$-triazin-3-yl $)-4,4^{\prime}$-bipyridine $\},{ }^{[55}$ $\left[\mathrm{Ru}_{2}(\mathrm{bpy})_{4}(\mathrm{btapb})\right]^{4+} \quad\left\{\right.$ btapb $=2,2^{\prime}$-bis(1,2,4-triazino[5,6-f]acenaphthylen3-yl)-4,4'-bipyridine $\},{ }^{[55]} \quad\left[\mathrm{Ru}_{2}(\mathrm{bpy})_{4}(\mathrm{bdptb})\right]^{4+} \quad\left\{2,2^{\prime}\right.$-bis(5,6-diphenyl-1,2,4triazin-3-yl)-4,4'-bipyridine $\},{ }^{[32,55]}\left[\left(\mathrm{Py}-3^{\prime}\right) \mathrm{TPP}-\mathrm{Ru}(\mathrm{phen})_{2} \mathrm{Cl}\right]^{+}\left\{\left(\mathrm{Py}-3^{\prime}\right) \mathrm{TPP}=\right.$ 5-(3'-pyridyl-10,15,20-triphenylporphyrin) $\},{ }^{[56]}$ and $\left[\mathrm{Ru}_{2}(\mathrm{bpy})_{4}(4-\mathrm{azo})\right]^{4+} .{ }^{[21]}$

\subsection{Molecular docking with DNA}

Molecular Docking is a method of drug design through studying the characteristics of the receptor and the interaction between the receptor and the drug molecule. Except for viscosity tests, molecular docking studies could provide direct and intuitive evidence about the binding of the complex to DNA. In order to further confirm the binding mode of $\left[\mathrm{Ru}_{2}(\mathrm{bpy})_{4}(\text { bip-phenol) }]^{4+}\right.$ to DNA, molecular docking studies were carried out. As shown in Fig. 5, the docking image revealed that the dinuclear complex interacts with duplex DNA through groove mode, which is consistent with the results of optical and hydrodynamic measurements. 


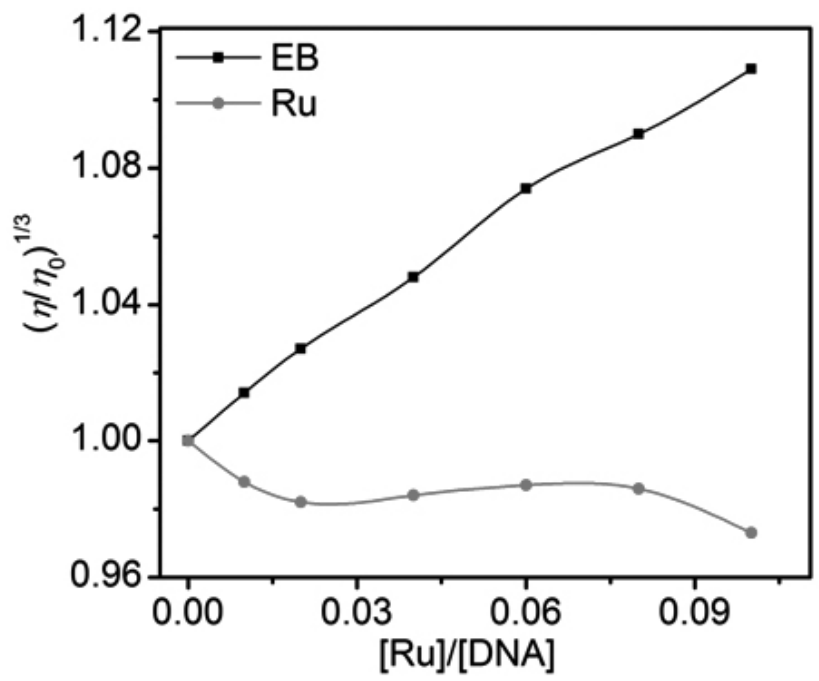

Fig. 4: Changes in relative viscosities of ct-DNA $(0.15 \mathrm{mM})$ upon successively increasing concentrations of the ruthenium complex and EB at $32.0 \pm 0.1^{\circ} \mathrm{C}$.

Table 3. Thermodynamic DNA binding parameters.

\begin{tabular}{|c|c|c|c|c|c|c|}
\hline DNA binder & Binding mode & $Z$ & $\begin{array}{c}\Delta G_{\text {obs }} \\
(\mathrm{KJ} / \mathrm{mol})\end{array}$ & $\begin{array}{c}\Delta G_{\mathrm{pe}} \\
(\mathrm{KJ} / \mathrm{mol})\end{array}$ & $\begin{array}{c}\Delta G_{\mathrm{t}} \\
\left(\Delta G_{\mathrm{t}} / \Delta G_{\mathrm{obs}}\right)\end{array}$ & Ref. \\
\hline$\left[\mathrm{Ru}_{2}(\mathrm{bpy})_{4}(\text { bip-phenol })\right]^{4+}$ & groove binding & 2.95 & -36.5 & -19.3 & $-17.2(43 \%)$ & this work \\
\hline ethidium bromide & intercalative & 0.85 & -32.2 & -5.0 & $-27.2(85 \%)$ & 41,43 \\
\hline daynomycin & intercalative & 0.95 & -37.7 & -5.9 & $-31.8(84 \%)$ & 41 \\
\hline$\left[\operatorname{Ru}\left(\text { phen }_{) 2}(\mathrm{dppz})\right]^{2+}\right.$ & intercalative & 2.15 & -37.2 & -13.8 & $-23.4(63 \%)$ & 43 \\
\hline$\left[\mathrm{Ru}_{2}(\mathrm{bpy})_{4}\left(\mathrm{ebipcH}_{2}\right)\right]^{4+}$ & intercalative & 2.8 & -34.3 & -18.1 & $-16.2(47 \%)$ & 15 \\
\hline$\left[\operatorname{Ru}(\text { phen })_{2}(\mathrm{cdpq})\right]^{+}$ & groove binding & 1.5 & -21.0 & -9.5 & $-11.5(55 \%)$ & 45 \\
\hline$\left[\operatorname{Ru}(\text { phen })_{3}\right]^{2+}$ & groove binding & 1.6 & -23.0 & -10.0 & $-13.0(57 \%)$ & 46 \\
\hline$\left[(\text { bpy })_{2} \mathrm{Ru}(\mathrm{Mebpy})\left(\mathrm{CH}_{2}\right)_{7}(\mathrm{Mebpy}) \mathrm{Ru}(\mathrm{bpy})_{2}\right]^{4+}$ & electrostatic binding & 2.50 & -23.6 & -16.0 & $-7.5(32 \%)$ & 41 \\
\hline
\end{tabular}

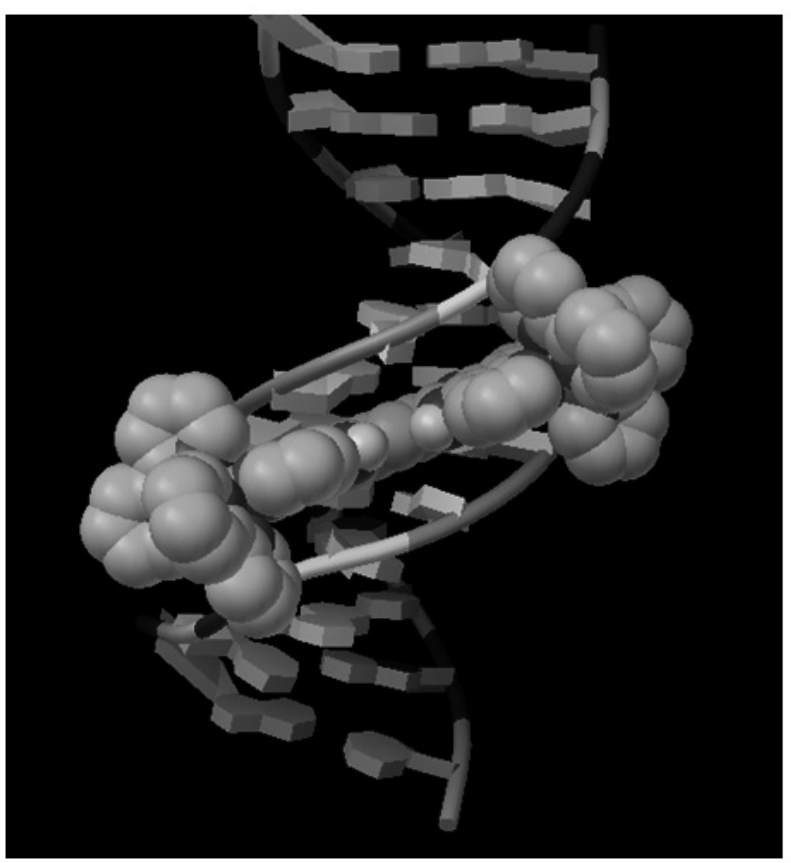

\subsection{Photocleavage of DNA}

The potential of the complex $[\mathrm{Ru} \text { (bpy),(bip-phenol) }]^{4+}$ to photocleave supercoiled pBR 322 DNA into nicked circular (Form II) and linear forms (Form III) was studied with agarose gel electrophoresis. When circular plasmid DNA is subject to electrophoresis, the fastest migration will be observed for the supercoil form (Form I). If one strand is cleaved (nicked), the supercoils will relax to give a slower moving open circular form (Form II). If both strands are cleaved, a linear form (Form III) that migrates between Form I and Form II will be produced. ${ }^{[57]}$ The present complex was found to possess the ability to photocleave plasmid DNA. Fig. 6 shows the gel electrophoresis separation of pBR 322 DNA after incubation with the complex and irradiation with UV light. As shown in Fig. 6, no obvious DNA cleavage was observed for the controls in the absence (lane 0) and in the presence of the complex in the dark (lane 1). While upon irradiation at $360 \mathrm{~nm}$ for only $15 \mathrm{~min}$, with increasing concentrations of the complex, the amount of Form I of pBR 322 DNA diminished gradually, whereas that of Form II increased, which indicates the occurrence of cleavage. Moreover, at a concentration of $10 \mu \mathrm{M}$, the complex has fully cleaved DNA, suggesting the effective DNA cleavage activity of the complex.

Fig. 5: Molecular docking model of the ruthenium complex with DNA (PDB 1D:1BNA). 


\section{$\left[\mathrm{Ru}_{2}(\mathrm{bpy})_{4}(\right.$ bip-phenol $\left.)\right]\left(\mathrm{ClO}_{4}\right)_{4}(\mu \mathrm{M})$}

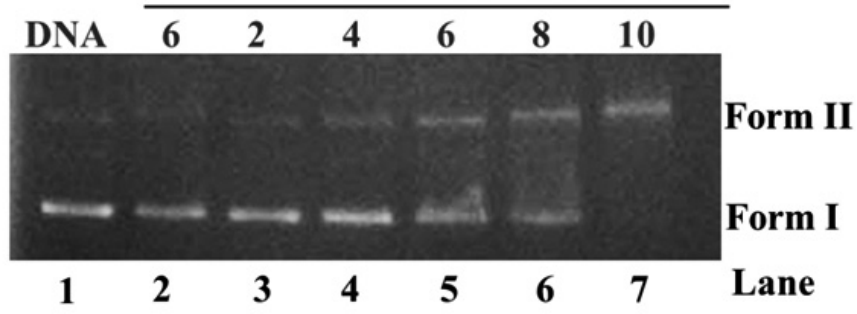

Fig. 6: Photoactivated cleavage of pBR 322 DNA in the presence of different concentrations of ruthenium complex after irradiation at $360 \mathrm{~nm}$ for $15 \mathrm{~min}$.

\section{CONCLUSIONS}

A dinuclear ruthenium complex $\left[\mathrm{Ru}_{2}(\mathrm{bpy})_{4}(\right.$ bip-phenol) $]\left(\mathrm{ClO}_{4}\right)_{4}$ was shown to exhibit a large DNA induced emission enhancement factor of 6.3 , which is favorable as compared to the $I / I_{0}$ values previously reported for many other dinuclear complexes. The spectroscopic titrations, steady-state emission quenching by $\left[\mathrm{Fe}(\mathrm{CN})_{6}\right]^{4}$, DNA competitive binding with ethidium bromide, DNA melting experiments, reverse salt effect and viscosity measurements, as well as molecular docking studies showed that the complex bound to ctDNA through groove mode with a DNA binding constant on the order of magnitude of $10^{6} \mathrm{M}^{-1}$. The complex was found to display efficient $\mathrm{pBR} 322$ DNA photocleavage activity, which fully cleaved DNA at a concentration of 6 $\mu \mathrm{M}$ under UV light irradiation for only $15 \mathrm{~min}$.

\section{ACKNOWLEDGMENTS}

The authors thank the National Natural Science Foundation (No. 21401038), Natural Science Foundation of Hebei Province (No. B2016201122), the Science and Technology Research and Development Plan Project of Baoding City (No.14ZF009), the Science and Technology Development Plan Project in Tai'an City (No. 2015GX2048), and the Scientific Research Foundation of Taishan University (No. Y-01-2014017).

\section{REFERENCES}

[1] J.K. Barton, E.D. Olmon, P.A. Sontz, Coord. Chem. Rev. 255, 619-634, (2011)

[2] S.S. Bhat, V.K. Revankar, R.V. Pinjari, S. Naveen, C. Bogar, K. Bhat, V.A. Kawade, New J. Chem. 41, 5513-5520, (2017)

[3] H.K. Liu, P.J. Sadler, Acc. Chem. Res. 44, 349-359, (2011)

[4] M.R. Gill, J.A. Thomas, Chem. Soc. Rev. 41, 3179-3192, (2012)

[5] B.J. Pages, D.L. Ang, E.P. Wright, J.R. Aldrich-Wright, Dalton Trans. 44 3505-3526, (2015)

[6] J.L. Morgan, C.B. Spillane, J.A. Smith, D.P. Buck, J.G. Collins, F.R. Keene, Dalton Trans. 10, 4333-4342, (2007)

[7] S.V. Sagar Babu, K.S.V. Krishna Rao, Y. Ill Lee, J. Chil. Chem. Soc. 62 3447-3453, (2017)

[8] K. Margandan, S.J.M. Jebastin, J. Chil. Chem. Soc. 62, 3691-3699, (2017)

[9] J. Aldrich-Wright, C. Brodie, E.C. Glazer, N.W. Luedtke, L. ElsonSchwab, Y. Tor, Chem. Commun. 1018-1019, (2004)

[10] S.A. Ezadyar, A.S. Kumbhar, A.A. Kumbhar, A. Khan, Polyhedron 36, $45-55,(2012)$

[11]C.C. Ju, A.G. Zhang, C.L. Yuan, X.L. Zhao, K.Z. Wang, J. Inorg. Biochem. 105, 435-443, (2011)

[12] C. Rajput, R. Rutkaite, L. Swanson, I. Haq, J.A. Thomas, Chem. Eur. J. 12, 4611-4619, (2006)

[13]H. Chao, Y.X. Yuan, F. Zhou, L.N. Ji, Trans. Met. Chem. 31, 465-469, (2006)

[14]P. Liu, B.Y. Wu, J. Liu, Y.C. Dai, Y.J. Wang, K.Z. Wang, Inorg. Chem. $\mathbf{5 5}, 1412-1422,(2016)$

[15]F.R. Liu, K.Z. Wang, G.Y. Bai, Y.A. Zhang, L.H. Gao, Inorg. Chem. 43, 1799-1806, (2004)

[16]J. Andersson, M. Li, P. Lincoln, Chem. Eur. J. 16, 11037-11046, (2010)

[17] A.G. Clark, M.N. Naufer, F. Westerlund, P. Lincoln, I. Rouzina, T. Paramanathan, M.C. Williams, Biochemistry 57, 614-619, (2018)

[18] A.A. Almaqwashi, T. Paramanathan, I. Rouzina, M.C. Williams, Nucleic
Acids Res. 44, 3971-3988, (2016)

[19] A.A. Almaqwashi, T. Paramanathan, P. Lincoln, I. Rouzina, F. Westerlund, M.C. Williams, Nucleic Acids Res. 42, 11634-11641, (2014)

[20] J. Andersson, P. Lincoln, J. Phys. Chem. B 115, 14768-14775, (2011)

[21] V. Gonzalez, T. Wilson, I. Kurihara, A. Imai, J.A. Thomas, J. Otsuki, Chem. Commun. 1868-1870, (2008)

[22] X.L. Zhao, Z.S. Li, Z.B. Zheng, A.G. Zhang, K.Z. Wang, Dalton Trans. 42, 5764-5777, (2013)

[23]A. Ghosh, P. Das, M.R. Gill, P. Kar, M.G. Walker, J.A. Thomas, A. Das, Chem. Eur. J. 17, 2089-2098, (2011)

[24]L. Li, H.M. Liu, X.K. Liu, S.Y. Liao, Y.T. Lan, Q. Wu, X.C. Wang, Q Wang, S.Y. Zhang, W.J. Mei, RSC Adv. 7, 23727-23734, (2017)

[25] Q. Wu, K.D. Zheng, S.Y. Liao, Y. Ding, Y.Q. Li, W.J. Mei, Organometallics 35, 317-326, (2016)

[26] Y.H. Chen, Q. Wu, X.C. Wang, Q. Xie, Y.Y. Tang, Y.T. Lan, S.Y. Zhang, W.J. Mei, Materials 9, 386, (2016)

[27] Q. Wu, T.F. Chen, Z. Zhang, S.Y. Liao, X.H. Wu, J. Wu, W.J. Mei, Y.H Chen, W.L. Wu, L.L. Zeng, Dalton Trans. 43, 9216-9225, (2014)

[28]Z.B. Zheng, Q.Y. Huang, Y.F. Han, J. Zuo, Y.N. Ma, Sens. Actuat. B 253, 203-212, (2017)

[29] V. Muthuraj, M. Umadevi, J. Mol. Struct. 1157, 201-209, (2018)

[30] W.X. Hong, H.W. Huang, T.W. Huang, X. Xu, Q.G. Han, G.F. Wang, H Xu, S. Duan, Y.H. Duan, X. Long, Y. Liu, Z.L. Hu, J. Inorg. Biochem. 180, 54-60, (2018)

[31] M. Mohanraj, G. Ayyannan, G. Raja, C. Jayabalakrishnan, Mat. Sci. Eng. C-Mater. 69, 1297-1306, (2016)

[32]C.W. Jiang, J. Inorg. Biochem. 98, 497-501, (2004)

[33] V. Muthuraj, M. Umadevi, J. Mol. Struct. 1157, 201-209, (2018)

[34]D. Suh, J.B. Chaires, Bioorg. Med. Chem. 3, 723-728, (1995)

[35]A.G. Zhang, Y.Z. Zhang, Z.M. Duan, K.Z. Wang, H.B. Wei, Z.Q. Bian, C.H. Huang, Inorg. Chem. 50, 6425-6436, (2011)

[36] J.Z. Wu, L. Yuan, J. Inorg. Biochem. 98, 41-45, (2004)

[37]F.M. O’Reilly, J.M. Kelly, New J. Chem. 22, 215-217, (1998)

[38] S. Mardanya, S. Karmakar, D. Mondal, S. Baitalik, Inorg. chem. 55, 3475 3489, (2016)

[39] S.J. Burya, D.A. Lutterman, C. Turro, Chem. Commun. 47, 1848-1850, (2011)

[40]M.M. Milutinović, A. Rilak, I. Bratsos, O. Klisurić, M. Vraneš, N Gligorijević, S. Radulović, Ž.D. Bugarčić, J. Inorg. Biochem. 169, 1-12, (2017)

[41] R.B. Nair, E.S. Teng, S.L. Kirkland, C.J. Murphy, Inorg. Chem. 37, 139 141, (1998)

[42] L. Xu, Y. Chen, H. Wei, W.S. Wu, Z.Z. Li, Y.W. Lin, H. Chao, L.N. Ji, Chem. Res. Chin. Univ. 30, 461-467, (2014)

[43] A. Ambroise, B.G. Maiya, Inorg. Chem. 39, 4264-4272, (2000)

[44]F. Gao, H. Chao, F. Zhou, Y.X. Yuan, B. Peng, L.N. Ji, J. Inorg. Biochem. 100, 1487-1494, (2006)

[45] J.M. Kelly, A.B. Tossi, D.J. McConnell, C. OhUigin, Nucleic Acids Res 13, 6017-6034, (1985)

[46] Y.J. Liu, W.J. Mei, J.Z. Lu, H.J. Zhao, L.X. He, F.H. Wu, J. Coord. Chem 61, 3213-3224, (2008)

[47] X.L. Hong, H. Chao, L.J. Lin, K.C. Zheng, H. Li, X.L. Wang, F.C. Yun, L.N. Ji, Helv. Chim. Acta. 87, 1180-1193, (2004)

[48] S. Satyanarayana, J.C. Dabrowiak, J.B. Chaires, Biochemistry 32, $2573-$ 2584, (1993)

[49]F. Leng, J.B. Chairs, M.J. Waring, Nucleic Acids Res. 31, 6191-6197, (2003)

[50]N.M. Gabra, B. Mustafa, Y.P. Kumar, C.S. Devi, A. Srishailam, P.V Reddy, K.L. Reddy, S. Satyanarayana, J. Fluoresc. 24, 169-181, (2014)

[51] Mudasir, K. Wijaya, E.T. Wahyuni, N. Yoshioka, H. Inoue, Biophys. Chem. 121, 44-50, (2006)

[52]F. Pierard, A.D. Guerzo, A.K. Mesmaeker, M. Demeunynck, J. Lhomme, Phys. Chem. Chem. Phys. 3, 2911-2920, (2001)

[53] S. Satyanarayana, J.C. Dabrowiak, J.B. Chaires, Biochemistry 31, 93199324, (1992)

[54]X.W. Liu, Y.M. Shen, Z.X. Li, X. Zhong, Y.D. Chen, S.B. Zhang, Spectrochim. Acta A 149, 150-156, (2015)

[55] C.W. Jiang, Eur. J. Inorg. Chem. 2004, 2277-2282, (2004)

[56] Y.N. Liu, T.F. Chen, Y.S. Wong, W.J. Mei, X.M. Huang, F. Yang, J. Liu, W.J. Zheng, Chem. Biol. Interact. 183, 349-356, (2010)

[57] Y.P. Kumar, C.S. Devi, A. Srishailam, N. Deepika, V.R. Kumar, P.V. Reddy, J. Fluoresc. 26, 2119-2132, (2016) 